Bisset, K. A. (1955). J. gen. Microbiol. 13, 442-445

\title{
Evidence from the Cytology of Azotobacter chroococcum of a Relationship with Rhizobium and the Bacillaceae
}

\author{
By K. A. BISSET \\ Department of Bacteriology, University of Birmingham
}

SUMMARY: The structure of the cell envelopes in Azotobacter chroococcum and the behaviour and mode of formation of the spore-like 'cysts' suggest that this organism has a close phylogenetic relationship with the Bacillaceae, and that accordingly the main genera of nitrogen-fixing bacteria, Azotobacter, Rhizobium, and Clostridium, have a relatively recent common origin.

Cytological studies upon Rhizobium spp. (Bisset \& Hale, $1951 a$; Bisset, 1952a) led to the rather surprising conclusion that this genus is a specialized member of the family Bacillaceae. Further studies upon Azotobacter chroococcum (Bisset \& Hale, 1953) led to the conclusion (Bisset, 1954) that these two important genera of nitrogen-fixing bacteria have numerous cytological characters in common. The evidence examined at that time included nuclear structures and gonidium-formation, but not, in the case of $A$. chroococcum, a detailed study of the cell envelopes and the characters of the resting-cell, usually called a cyst. It is the purpose of the present paper to show that new evidence strongly reinforces the concept that Azotobacter and Rhizobium are related, and are specialized members of the Bacillaceae.

\section{METHODS}

Seven strains of Azotobacter chroococcum were obtained through the courtesy of $\mathrm{Mr}$ J. C. Lawrence, by whom they were isolated, in this Department, from soil samples taken in Warwickshire and Somerset. I am also indebted to Mr Lawrence for an indication of the ease with which these strains could be grown upon a medium consisting of $2 \%(\mathrm{w} / \mathrm{v})$ potato meal with $2 \%(\mathrm{w} / \mathrm{v})$ agar in tap water. In contrast to most of the recommended media, this simple method produced luxuriant growth in $24 \mathrm{hr}$. at $25^{\circ}$, thus enabling very young cultures to be studied and compared with much older sporogenous cultures.

The stains employed were: the cell-wall method of Hale (1953); the Victoria blue method of Robinow \& Murray (1953); the nitric acid spore stain of Robinow (1951). The latter method is not really a cytological stain, but is rather a test for a diagnostic character of bacterial endospores (Bisset \& Hale, $1951 b)$.

\section{RESULTS}

\section{Cell envelopes}

When stained by Victoria blue, the strains of Azotobacter examined gave an appearance which can be regarded as reasonably characteristic of the genus, and readily recognizable ( $\mathrm{Pl}$. 1, fig. 1$)$. The capsule was clearly visible, the cell 
wall less obvious, and the cytoplasm in the condition known as 'vacuolated' (Bisset \& Hale, 1953). Less deeply stained by the same method, the cells were seen to be subdivided by darker masses representing stages of cross-wall development (Pl. 1, figs. 2, 3). Young cultures stained by Hale's method showed a structure surprisingly like that of typical Bacillus spp. (Bisset, 1952b) with rods divided by complete cross-walls and subdivided by developing walls (Pl. 1, figs. 4, 5). The development of the cross-walls as an ingrowth was also well seen, in this exceptionally large bacterium (arrows in Pl. 1, figs. 4, 5). By contrast, the same strains, when grown on the chemically defined medium employed by Bisset \& Hale (1953), although exhibiting cross-walls, showed a much less Bacillus-like appearance (Pl. 1, fig. 6).

\section{Spores}

After a period of 2 or 3 weeks upon potato agar, most of the vegetative cells were transformed into so-called 'cysts'. These resembled spores in being refractile and difficult to stain when mature, although less so when immature. They were also sporelike in being formed within the mother-cell, a state of affairs which is decidedly not suggested by the previous title of cyst (Pl. 1, figs. 7, 8). Under the influence of $\mathrm{N}$-nitric acid the nuclear material of mature spores is partially or completely ejected (Pl. 1, fig. 9). This is suggestive of protoplasmic turgor, and is highly characteristic of the endospores of Bacillaceae (Bisset \& Hale, 1951 b).

The resemblance to true endospores was so complete, from the morphological viewpoint, that it was decided to test their resistance to heat. Five strains were tested; sporogenous cultures, 3 weeks old, were compared with $24 \mathrm{hr}$. cultures of the same strains. A loopful of culture was emulsified in $1 \mathrm{ml}$. sterile saline in a screw-capped bijou bottle. These were raised rapidly to $85^{\circ}$ in a water-bath, and held at that temperature for 5 min.; the temperature being taken by means of a thermometer in a control bottle. The bottles were then opened, sampled, closed, raised to $95^{\circ}$ for $5 \mathrm{~min}$. and re-sampled. Sampling was repeated after heating at $100^{\circ}$ for 5,10 and 15 min.

The samples from the $\mathbf{2 4} \mathrm{hr}$. vegetative cultures failed to grow at all stages; all the sporogenous cultures survived $5 \mathrm{~min}$. at $85^{\circ}$; two of these survived $5 \mathrm{~min}$. at $95^{\circ}$ and one survived the entire period of the test. This especially resistant spore was also peculiar in being slightly smaller, and a more pointed oval in outline than the others.

\section{DISCUSSION}

In addition to the character of nitrogen-fixation, it has already been pointed out (Bisset, 1954) that Azotobacter spp. and Rhizobium spp. have a number of characters in common. These are known to include: a tendency to Grampositivity at certain stages in the life-cycle of an apparently Gram-negative organism; the mode of gonidium-formation; the mode of germination of the resting stage; the simultaneous possession of flagella and a mucoid capsule; relatively large size. The Bacillus-like characters of morphology and 
spore-formation in Rhizobium (Bisset, 1952a) are now found to be duplicated in Azotobacter chroococcum. The cell walls of young cultures upon potato agar have so marked a resemblance to those of the typically large, 'rough' types of Bacillus that this alone would give grounds for suspicion of relationship. But the 'cyst' also possesses a number of such endospore-like characters as formation within the mother-cell, refractility, resistance to staining, heat-resistance and nuclear turgor. It is the opinion of the present writer (cf. Bisset, 1950; Bisset \& Hale, $1951 b$ ) that this nuclear turgor, representing some degree of concentration and dehydration of protein, is responsible for the resistant character of bacterial endospores. Neither has so far been found without the other.

If, as is now suggested, the genera Azotobacter and Rhizobium are both rather aberrant members of the Bacillaceae, these important nitrogen-fixing bacteria are brought into much closer taxonomic connexion with the remaining important group of bacteria which possess this character, the Clostridium butyricum group. It was noted that the Rhizobium spp. examined by Bisset (1952 a) most closely resembled the aerogenic megasporous species of Bacillus, which themselves resemble Clostridium at least as much as they do the typical aerobic species. There is thus evidence obtainable from purely morphological studies which suggests a close connexion between the major groups of nitrogen-fixing bacteria.

A point of cytological interest emerges from the evidence presented here. The large size of Azotobacter chroococcum enables the centripetal ingrowth of the cross-walls to be demonstrated quite clearly. This is contrary to my previous belief, but the question had already been resolved by the admirable sections of Chapman \& Hillier (1953); the evidence in Pl. 1, figs. 4 and 5, serves merely to confirm their views. On the other hand, the cytoplasmic septa which precede the cross-wall are especially well seen in Pl. 1, fig. 2, and are quite obviously large entire structures, despite the potentially disruptive effect of the "vacuolated' cytoplasm. Their appearance does not confirm the view of Chapman \& Hillier that these septa are an illusion and consist of an unresolved pattern of granules near the ingrowing edge of the cross-wall.

\section{REFERENCES}

Bisset, K. A. (1950). Evolution in bacteria and the significance of the bacterial spore. Nature, Lond. 166, 431.

Bisset, K. A. (1952a). Complete and reduced life-cycles in Rhizobium. J. gen. Microbiol. 7, 233.

Bisset, K. A. (1952b). Bacteria. Edinburgh: Livingstone.

Bisset, K. A. (1954). The cytology and reproductive elements of nitrogen-fixing bacteria. Rapp. 8th Int. bot. Congr. Section 21, p. 34.

Bisset, K. A. \& HAle, C. M. F. (1951 $a)$. The production of swarmers in Rhizobium sp. J. gen. Microbiol. 5, 592.

Bisset, K. A. \& Hale, C. M. F. (1951b). Observations upon the bacterial spore nucleus. J. Hyg., Camb. 49, 201.

Bisset, K. A. \& Hale, C. M. F. (1953). The cytology and life-cycle of Azotobacter chroococcum. J. gen. Microbiol. 8, 442. 
Journal of General Microbiology, Vol. 13, No. 3

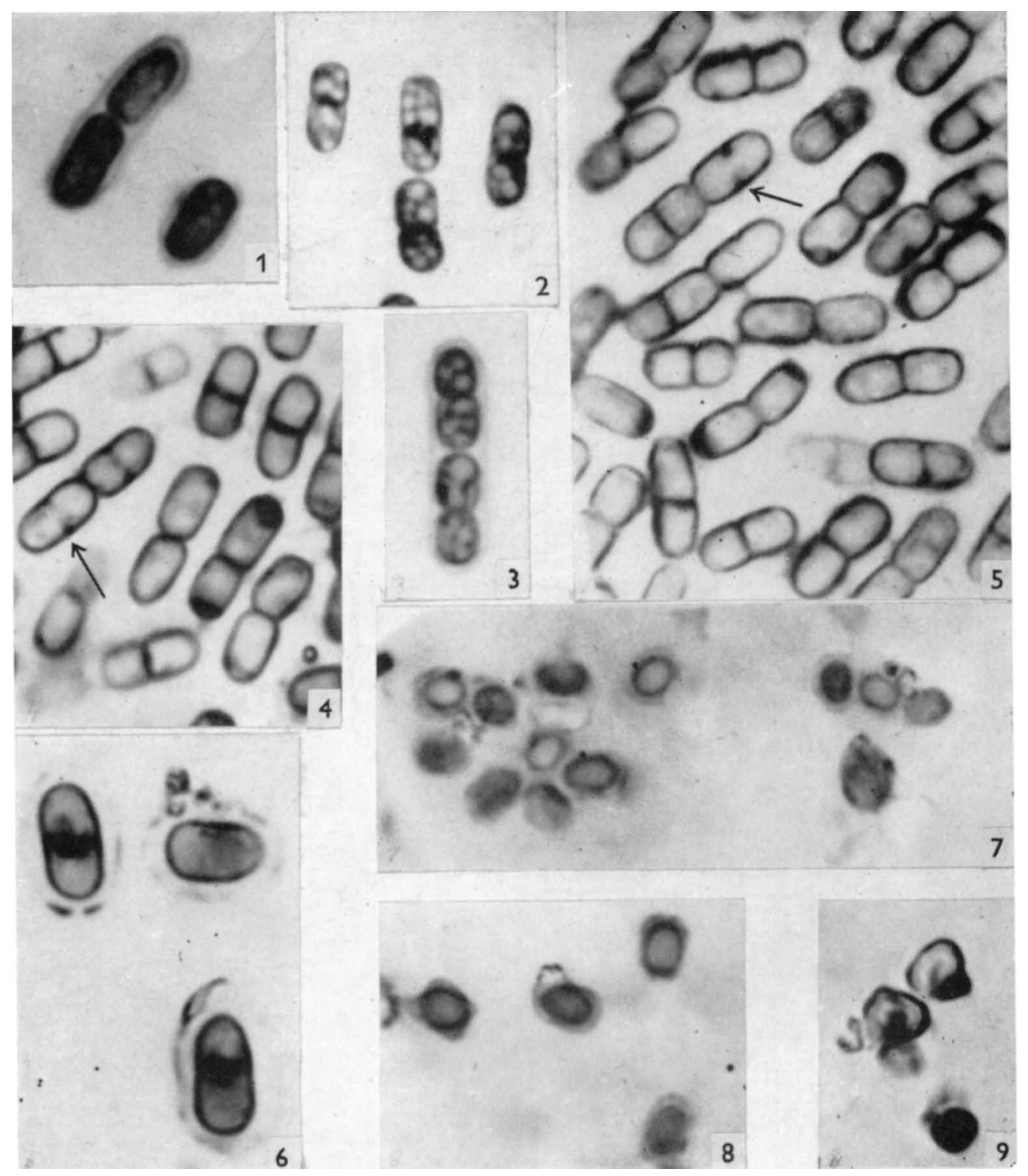

K. A. Bisset-Cytology of Azotohacter chroococcul. Plate 1 
Chapman, G. B. \& Hillier, J. (1953). Electron microscopy of ultra-thin sections of bacteria. J. Bact. 66, 362.

HaLe, C. M. F. (1953). The use of phosphomolybdic acid in the mordanting of bacterial cell walls. Lab. Practice, $2,115$.

Robinow, C. F. (1951). Observations on the structure of Bacillus spores. J. gen. Microbiol. 5, 439.

Robinow, C. F. \& Murray, R. G. E. (1953). The differentiation of cell wall, cytoplasmic membrane and cytoplasm of Gram-positive bacteria by selective staining. Exp. Cell Research, 4, 390.

\section{EXPLANATION OF PLATE}

Figs. 1-3. Azotobacter chroococcum, $24 \mathrm{hr}$. on potato agar. 'Vacuolated' cytoplasm, capsule and cytoplasmic septa seen. Victoria blue. $\times 3000$.

Figs. 4, 5. As figs. 1-3. Cell walls of a distinctly Bacillus-like pattern with centripetally ingrowing cross-walls. Hale's method. $\times 3000$.

Fig. 6. Azotobacter chroococcum. 3 to 4-day growth on chemically defined medium. Much less Bacillus-like, but showing well-marked cross-walls. Hale's method. $\times 3000$.

Figs. 7, 8. Azotobacter chroococcum. Spores ('cysts') from 3-week cultures on potato agar. Mature spores are refractile and resist the stain; some are enclosed in remnants of sporangium. Hale's method. $\times \mathbf{3 0 0 0}$.

Fig. 9. As figs. 7, 8. Nucleus ejected under effect of $\mathrm{N}$-nitric acid, crystal violet. $\times 3000$.

(Received 10 May 1955) 